\title{
5: $132037272-132046267$
}

National Cancer Institute

\section{Source}

National Cancer Institute. 5: 132037272-132046267. NCI Thesaurus. Code C45119.

Physical location of IL4_Gene 